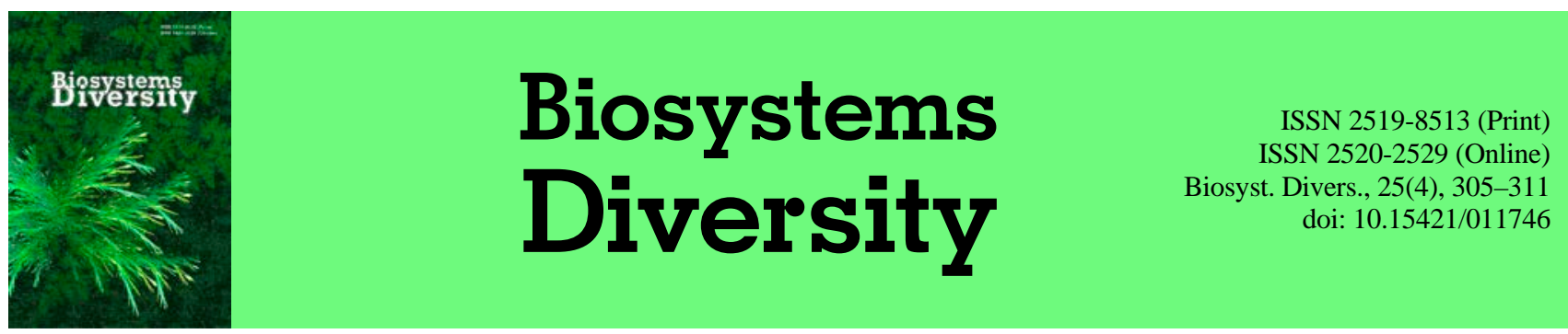

\title{
Species composition of Dothideomycetes in the anthropogenically transformed ecosystems of the steppe zone of Ukraine
}

\author{
O. V. Korolyova
}

Mykolayiv V. O. Sukhomlynsky National University, Mykolayiv, Ukraine

Article info

Received 29.10.2017

Received in revised form 17.11.2017

Accepted 18.11.2017

Mykolayiv V. O. Sukhomlynsky National University,

Nikolska st., 24,

Mykolayiv, 54030, Ukraine.

Tel.: +38-051-276-99-49

E-mail:

koroleva1975@gmail.com
Korolyova, O. V. (2017). Species composition of Dothideomycetes in the anthropogenically transformed ecosystems of the steppe zone of Ukraine. Biosystems Diversity, 25(4), 305-311. doi:10.15421/011746

The article considers the species composition of the Dothideomycetes and its structural characteristics in conditions of anthropogenically transformed ecosystems of the steppe zone of Ukraine. The materials of the work were the original mycological collection carried out as part of the mycological survey of this territory during 2008-2016, as well as the materials of the herbarium of the Institute of Botany named after M. Kholodny of the National Academy of Sciences of Ukraine. Herbarium collection and identification of the samples were performed in accordance with the generally accepted methods of cameral processing of xylotrophic, herbotrophic and coprothrophic micromycetes. To establish the taxonomic affiliation of species, the method of light microscopy was applied. As a result of our research, the species diversity of ascolocular fungi (Dothideomycetes) has been established in the anthropogenically transformed ecosystems of the steppe zone of Ukraine, which includes 156 species from 43 genera 19 families 5 orders and groups of taxa of Incertae sedis of the subclasses Dothideomycetidae and Pleosporomycetidae. The characteristic features of the taxonomic structure of the investigated mycobiota are the predominance of representatives of the order of Pleosporales, the families Cucurbitariaceae and Mycosphaerellaceae, the genera Cucurbitaria and Mycosphaerella. In the ecological structure of mycobiota in anthropogenically transformed ecosystems saprotrophic and xylotrophic species dominated. The ascolocular fungi species are form consortium connections with 178 species of vascular plants from 112 genera of 51 families, with the largest number of micromycetes (65 species) noted on plants of the Rosaceae. An analysis of the abundance of species in anthropogenically transformed ecosystems of the investigated area showed that $47 \%$ of the species are randomly distributed. Widespread species are Dothidea sorbi (Wahlenb.) Sacc., Cucurbitaria caraganae P. Karst., C. amorphae (Wallr.) Fuckel, Botryosphaeria dothidea (Moug.) Ces. \& De Not., Otthia spiraeae (Fuckel) Fuckel. In the anthropogenically transformed ecosystems of the steppe zone of Ukraine, in comparison with natural ecosystems, the proportion of species from the genera Cucurbitaria and Mycosphaerella increases quantitatively, and the proportion of Leptosphaeria and Pleospora species decreases. An increase in the proportion of hemibiotrophic species in the ecological structure can be considered a characteristic feature of anthropogenic influence on mycobiota . Comparative analysis of quantitative and qualitative indicators of the mycobiota structure combined with spatial and temporal changes of these indicators can serve as an instrument for indicating its anthropogenic transformation. It would be promising to conduct further research on changes in the species structure of micromycetes exposed to various types of anthropogenic impact in terrestrial ecosystems of the steppe zone of Ukraine.

Keywords: ascolocular fungi; species diversity; taxonomic structure; ecological structure; anthropogenically altered habitats

\section{Видовий склад грибів класу Dothideomycetes в антропогенно трансформованих екосистемах степової зони України}

\author{
О. В. Корольова
}

\section{Миколаївський національний університет імені В. О. Сухомлинського, Миколаїв, Україна}

Розглянуто видовий склад грибів класу Dothideomycetes та особливості його таксономічної та екологічної структури в умовах антропогенно трансформованих екосистем степової зони України. Оригінальні мікологічні збори виконані в рамках мікологічного обстеження цієї території протягом 2008-2016 рр., також використано матеріали гербарію Інституту ботаніки імені М. Г. Холодного НАН України $(\mathrm{KW})$. Збирання, гербаризація та ідентифікація зразків виконані згідно із загальноприйнятими методиками камеральної обробки ксилотрофних, герботрофних і копротрофних мікроміцетів. Для встановлення таксономічної належності видів застосовано метод світлової мікроскопії. У результаті наших досліджень установлено різноманіття локулоаскоміцетів антропогенно трансформованих екосистем степової зони України, яке включає 156 видів із 43 родів 19 родин 5 порядків і групи таксонів Incertae sedis підкласів Dothideomycetidae та Pleosporomycetidae класу Dothideomycetes. Характерні риси таксономічної структури дослідженої мікобіоти - переважання представників порядку Pleosporales, родин Cucurbitariaceae та Mycosphaerellaceae, родів Cucurbitaria та Mycosphaerella. В екологічній структурі дослідженої мікобіоти відмічалося переважання сапротрофних та ксилотрофних видів. Виявлені види грибів утворюють консортивні зв'язки з 178 видами судинних рослин зі 112 родів 51 родини, причому більшу кількість мікроміцетів (65 видів) відмічено на рослинах родини Rosaceae. Аналіз достатку видів в антропогенно трансформованих біотопах дослідженої території показав, що 47\% видів 
трапляються випадково. Розповсюдженими видами виявилися Dothidea sorbi (Wahlenb.) Sacc., Cucurbitaria caraganae P. Karst., C. amorphae (Wallr.) Fuckel, Botryosphaeria dothidea (Moug.) Ces. \& De Not., Otthia spiraeae (Fuckel) Fuckel. У мікоценозах антропогенно трансформованих екосистем степової зони України, порівняно з природними, кількісно зростає частка видів із родів Сисигbitaria та Mycosphaerella, а також зменшується частка видів Leptosphaeria i Pleospora. Характерна ознака антропогенних змін мікобіоти збільшення в екологічній структурі частки гемібіотрофних видів. Порівняльний аналіз кількісних і якісних показників структури мікобіоти, просторових і часових змін цих показників може виступати інструментом індикації ії антропогенної трансформації. Перспективи подальших досліджень - оцінка змін видової структури мікроміцетів за різних типів антропогенного впливу в наземних екосистемах степової зони України.

Ключові слова: локулоаскоміцети; видове різноманіття; таксономічна структура; екологічна структура; антропогенно змінені місцезростання

\section{Вступ}

Унаслідок впливу діяльності людини на природні екосистеми відбувається їх докорінна зміна та утворення антропогенно змінених, порушених і перетворених біотопів, що значно відрізняються від первинних. Природні ландшафти степової зони України перебувають під значним антропогенним впливом і зміни у природних екосистемах часто набувають незворотного характеру. Територія степової зони на 75-90\% трансформована людиною, за винятком площ степових заповідників, які можуть виступати еталонними ділянками 3 мінімальним антропогенним навантаженням (Protopopova, 1991). Біота, як компонент екосистеми, у першу чергу зазнає змін, що дозволяє говорити про антропогенну трансформацію не тільки флори та фауни, а й мікобіоти (Marfenina, 2005; Newbound et al., 2010).

Антропогенні фактори тією чи іншою мірою впливають на різноманіття, структурні та функціональні характеристики угруповань грибів різних таксономічних груп (Terehova, 2007; Pereira et al., 2016), причому зворотна реакція грибних організмів дає підстави вважати їх біоіндикаторами екологічного стану середовища існування (Mendes et al., 1998). Добре досліджені антропогенні зміни мікобіоти грунтових грибів, зокрема, за впливу забруднення пестицидами (Mandić et al., 2005), важкими металами (Bespalova et al., 2006), радіонуклідами (Dion and Nautiyal, 2008), пірогенного навантаження (Buscardo et al., 2015). Багато уваги також приділено вивченню дереворуйнівних грибів штучних лісонасаджень (Pavlidis et al., 2005; Blinkova and Ivanenko, 2014), лісових господарств (Juutilainen et al., 2017), промислових зон (Stavishenko and Kshnyasev, 2013), урбоекотопів (Terho et al., 2007; Blinkova and Ivanenko, 2016). Роль грибів відділу Dothideomycetes як біоіндикаційних об'єктів з'ясована недостатньо, однак окремі види фітотрофних локулоаскоміцетів наводяться у складі мікобіоти під час вивчення штучних і різною мірою антропогенно трансформованих ландшафтів (Tomoshevich, 2009; Snieškienè et al., 2016). У сучасних літературних джерелах також представлені дослідження з біології та екології окремих видів Dothideomycetes (Lee, 2016; Ji et al., 2017), асоційованих із різними видами рослин-господарів в антропогенних умовах (Rodríguez-Gálvez et al., 2017; Vivas et al., 2017), у тому числі інтродуцентами (Raghavendra et al., 2017). Серед них найповніше розглянуті представники порядку Botryosphaeriales, збудники раку та відмирання деревини сільськогосподарських (Mehl et al., 2017), лісотвірних (Sakalidis et al., 2011; Lawrence et al., 2017) і декоративних рослин (Pavlic-Zupanc et al., 2017; Pelleteret et al., 2017).

Початковий етап моніторингових досліджень - критична інвентаризація мікобіоти та встановлення ії характерних рис у досліджених умовах, із подальшим виявленням можливості моніторингу за цими параметрами. У системі мікологічного моніторингу найбільш показові такі характеристики мікобіоти як видовий склад, структура грибної біомаси, відсоток меланізованих форм мікроміцетів (Terehova, 2007). Як індикаційні ознаки доцільно також використовувати структурні особливості грибних угруповань (Matsumura and Fukuda, 2013; Tomoshevich and Banaev, 2013). Мета цієї статті - встановити різноманіття, таксономічну та екологічну структуру видового складу грибів відділу Dothideomycetes (локулоаскоміцетів) в антропогенно трансформованих екосистемах степової зони України, виявити характерні риси дослідженої мікобіоти та можливостей моніторингу за цими параметрами.

\section{Матеріал і методи досліджень}

Матеріал - оригінальні мікологічні збори 3 антропогенно трансформованих біотопів степової зони України, виконані протягом 2008-2016 pp., а також матеріали гербарію Інституту ботаніки імені М. Г. Холодного НАН України (KW). Досліджено основні типи ландшафтів антропогенно перетворених територій за класифікацією В. В. Протопопової (Protopopova, 1991). Для порівняльного аналізу використано характеристики видових комплексів локулоаскоміцетів природних угруповань степової зони, розглянуті в наших попередніх статтях (Korol'ova, 2016).

Степова зона займає близько 40\% території України та охоплює Причорноморську низину, південну частину Придніпровської височини та Придніпровської низовини, а також рівнини Кримського півострова. Географічні межі степової зони України визначаються за монографією «Геоботанічне районування Української РСР» в їі сучасній інтерпретації. За геоботанічним районуванням територія степової зони відповідає Понтичній степовій провінції Євразійської степової області, яка включає Чорноморсько-Азовську степову підпровінцію з 14 геоботанічними округами та Середньодонську степову підпровінцію із Сіверськодонецьким геоботанічним округом. Природна степова рослинність території представлена лучними, петрофітними, різнотравно-злаковими, злаковими, піщаними, полиново-злаковими, полиновими степами. Степові ділянки різною мірою антропогенно перетворені, але залишки еталонної природної рослинності збереглися у складі степових заповідників (Korol'ova, 2016).

Збирання, гербаризація та ідентифікація зразків виконані за загальноприйнятими методиками камеральної обробки ксилотрофних, герботрофних і копротрофних мікроміцетів (Miller et al., 2004); для встановлення таксономічної належності видів застосовано метод світлової мікроскопії. Для ідентифікації видів локулоаскоміцетів використано релевантні визначники (Sivanesan, 1984; Ellis and Ellis, 1987) з урахуванням сучасних таксономічних зведень, видові назви грибів наведені за базою даних «Index Fungorum». Результати досліджень біометрично опрацьовані за допомогою коефіцієнта дискримінації Стугрена - Радулеску (Stogran Radulesku Index); розподіл видів за чотирма категоріями рясності проведений за шкалою Стівенсона (Leont'ev, 2008).

\section{Результати та їх обговорення}

У результаті наших досліджень в антропогенних біотопах степової зони України відмічено 156 видів локулоаскоміцетів із 43 родів 19 родин 5 порядків і групи таксонів Incertae sedis підкласів Dothideomycetidae та Pleosporomycetidae класу Dothideomycetes (табл. 1). У таксономічній структурі домінують представники підкласу Pleosporomycetidae (123 види, 79,0\%), підклас Dothideomycetidae представлений значно меншою кількістю видів (31 вид, 20\%). Серед порядків кількісно переважає порядок Pleosporales - 101 вид (табл. 1). У межах цього порядку домінували родини Cucurbitariaceae (24), Leptosphaeriaceae (19), Lophiostomataceae (13), Pleosporaceae (12). Решта порядків - Capnodiales, Botryosphaeriales, Dothideales, Hysteriales - нараховують 24, 15 та по 7 видів відповідно.

Порівняння виявленого складу порядків локулоаскоміцетів із таким у природних угрупованнях степової зони України (Korol'ova, 2016) показало їх близьку видову насиченість (рис. 1). Спектри порядків практично збігаються, але мікобіота в антропогенних екосистемах характеризується дещо меншою часткою видів по- 
рядку Pleosporales, дещо більшою часткою Botryosphaeriales, Hysteriales, Capnodiales, а також в них не були відмічені представники порядку Patellariales.

У складі родин дослідженої мікобіоти переважають Cucurbitariaceae та Mycosphaerellaceae (24 и 23 види відповідно), дещо меншою кількістю представлені Leptosphaeriaceae (19), Botryosphaeriaceae (15), Lophiostomataceae (13) та Pleosporaceae (12), решта 13 родин включають по 1-7 видів (табл. 1). Десять провідних родин об’єднують 124 види або 80\% загальної кількості видів. Порівняння видового складу провідних родин локулоаскоміцетів в антропогенних та природних екосистемах показало їх різну видову насиченість (рис. 2), незважаючи на схожість родинних спектрів.

\section{Таблиця 1}

Співвідношення таксонів грибів класу Dothideomycetes в антропогенно трансформованих екосистемах степової зони України

\begin{tabular}{|c|c|c|c|c|c|}
\hline Підклас & Порядок & Родина & Рід & $\begin{array}{l}\text { Кількість } \\
\text { видів }\end{array}$ & $\begin{array}{l}\text { Частка } \\
\text { від } \\
\text { кілько- } \\
\text { сті, \% } \\
\end{array}$ \\
\hline \multirow{6}{*}{$\begin{array}{l}\text { Dothideo- } \\
\text { mycetidae }\end{array}$} & \multirow{3}{*}{ Dothideales } & Dothideaceae & Dothidea & 3 & 2,0 \\
\hline & & \multirow{2}{*}{ Dothioraceae } & Dothiora & 3 & 2,0 \\
\hline & & & Saccothecium & 1 & 0,6 \\
\hline & \multirow{3}{*}{ Capnodiales } & Davidiellaceae & Davidiella & 1 & 0,6 \\
\hline & & \multirow{2}{*}{$\begin{array}{l}\text { Mycosphaere- } \\
\text { llaceae }\end{array}$} & Mycosphaerella & 22 & 14,0 \\
\hline & & & Sphaerulina & 1 & 0,6 \\
\hline \multirow{35}{*}{$\begin{array}{l}\text { Pleosporo- } \\
\text { mycetidae }\end{array}$} & \multirow{27}{*}{ Pleosporales } & Cucurbitariaceae & Cucurbitaria & 24 & 15,4 \\
\hline & & $\begin{array}{l}\text { Didymosphae- } \\
\text { riaceae }\end{array}$ & Didymosphaeria & 6 & 3,8 \\
\hline & & \multirow[t]{2}{*}{ Leptosphaeriaceae } & Leptosphaeria & 16 & 10,3 \\
\hline & & & Ophiobolus & 3 & 2,0 \\
\hline & & \multirow{4}{*}{ Lophiostomataceae } & Cilioplea & 1 & 0,6 \\
\hline & & & Lophiostoma & 7 & 4,5 \\
\hline & & & Platystomum & 2 & 1,3 \\
\hline & & & Lophiotrema & 3 & 2,0 \\
\hline & & \multirow{2}{*}{ Massarinaceae } & Keissleriella & 1 & 0,6 \\
\hline & & & Massarina & 3 & 2,0 \\
\hline & & Melanommataceae & Karstenula & 1 & 0,6 \\
\hline & & Montagnulaceae & Kalmusia & 2 & 1,3 \\
\hline & & Mytilinidiaceae & Lophium & 1 & 0,6 \\
\hline & & \multirow{2}{*}{ Phaeosphaeriaceae } & Nodulosphaeria & 1 & 0,6 \\
\hline & & & Phaeosphaeria & 2 & 1,3 \\
\hline & & \multirow{2}{*}{ Pleomassariaceae } & Splanchnonema & 2 & 1,3 \\
\hline & & & Trematosphaeria & 2 & 1,3 \\
\hline & & \multirow{4}{*}{ Pleosporaceae } & Lewia & 2 & 1,3 \\
\hline & & & Pleospora & 7 & 4,5 \\
\hline & & & Pyrenophora & 1 & 0,6 \\
\hline & & & Sporormiella & 2 & 1,3 \\
\hline & & Tubeufiaceae & Rebentischia & 1 & 0,6 \\
\hline & & \multirow{2}{*}{ Venturiaceae } & Venturia & 5 & 3,2 \\
\hline & & & Platychora & 1 & 0,6 \\
\hline & & \multirow{3}{*}{ Incertae sedis } & Didymella & 3 & 2,0 \\
\hline & & & Herpotrichia & 1 & 0,6 \\
\hline & & & Phaeosphaeriopsis & 1 & 0,6 \\
\hline & \multirow{4}{*}{$\begin{array}{l}\text { Botryo- } \\
\text { sphaeriales }\end{array}$} & \multirow{4}{*}{ Botryosphaeriaceae } & Botryosphaeria & 5 & 3,2 \\
\hline & & & Guignardia & 3 & 2,0 \\
\hline & & & Otthia & 6 & 3,8 \\
\hline & & & Phaeobotryon & 1 & 0,6 \\
\hline & \multirow{4}{*}{ Hysteriales } & \multirow{4}{*}{ Hysteriaceae } & Hysterium & 2 & 1,3 \\
\hline & & & Hysterobrevium & 1 & 0,6 \\
\hline & & & Hysterographium & 2 & 1,3 \\
\hline & & & Hysteropatella & 2 & 1,3 \\
\hline \multirow{2}{*}{$\begin{array}{l}\text { Dothideo- } \\
\text { mycetes, } \\
\text { incertae sedis }\end{array}$} & & \multirow[b]{2}{*}{-} & Leptospora & 1 & 0,6 \\
\hline & & & Pseudopleospora & 1 & 0,6 \\
\hline Разом & 5 & 19 & 43 & 156 & 100 \\
\hline
\end{tabular}

В антропогенних біотопах порівняно 3 природними майже удвічі зростає частка видів родини Cucurbitariaceae, утричі - родини Botryosphaeriaceae, значно підвищується кількість видів Venturiaceae та Hysteriaceae, тоді як у природних біотопах основну роль відіграють представники Leptosphaeriaceae та Pleosporaceae (Korol'ova, 2016). Тільки в антропогенних біотопах на території степової зони відмічені представники родин Mytilinidiaceae та Tubeufiaceae. Серед родів дослідженої мікобіоти домінують Cucurbitaria (24 видів) та Mycosphaerella (22), представники яких складають 29\% загального видового багатства. Значну кількість видів нараховує рід Leptosphaeria (16 видів, 10\%). У природних біотопах, на відміну від антропогенних, домінують представники Leptosphaeria та Pleospora (рис. 3). У цілому, кількість спільних видів у порівнюваних мікобіотах незначна, або такі відсутні (рис. 3).

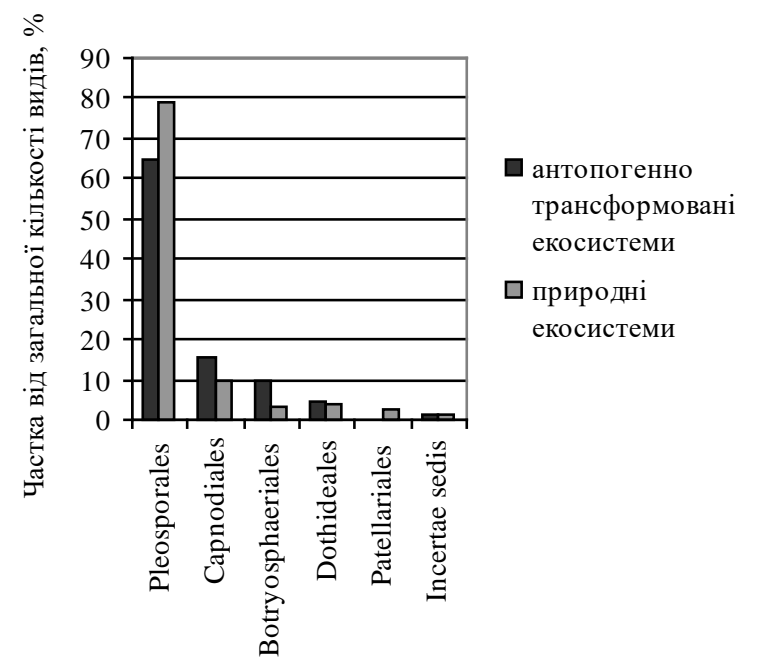

Рис. 1. Відсоткове співвідношення складу порядків класу Dothideomycetes в антропогенно трансформованих та природних екосистемах степової зони України

Поряд із цим, на антропогенно трансформованих територіях знайдено представників 11 родів: Herpotrichia, Hysterium, Hysterobrevium, Hysterographium, Hysteropatella, Karstenula, Keissleriella, Lophium, Phaeosphaeriopsis, Platychora, Rebentischia, що не відмічалися у природних місцезростаннях. У цілому, в антропогенно трансформованих екосистемах відмічено 108 видів локулоаскоміцетів, які не траплялися у природних екосистемах дослідженої території. Таким чином, умови антропогенних місцезростань зумовлюють формування специфічних комплексів локулоаскоміцетів.

Аналіз трофічних особливостей видів локулоаскоміцетів досліджених місцезростань показав переважання сапротрофів (106 видів), значно меншою кількістю видів представлені гемібіотрофи (48) та біотрофи (2). Особливість трофічної диференціації локулоаскоміцетів в антропогенно трансформованих екосистемах порівняльне переважання гемібіотрофних видів, - в 2,5 раза більше, ніж відмічене у природних степових угрупованнях, та в 6 разів більше, ніж у природних лісових угрупованнях степової зони (Коrol'ova, 2016). Переважання гемібіотрофних видів пояснюється наявністю широкого спектра рослин-господарів, які нерідко додатково ослаблені дією антропогенних чинників.

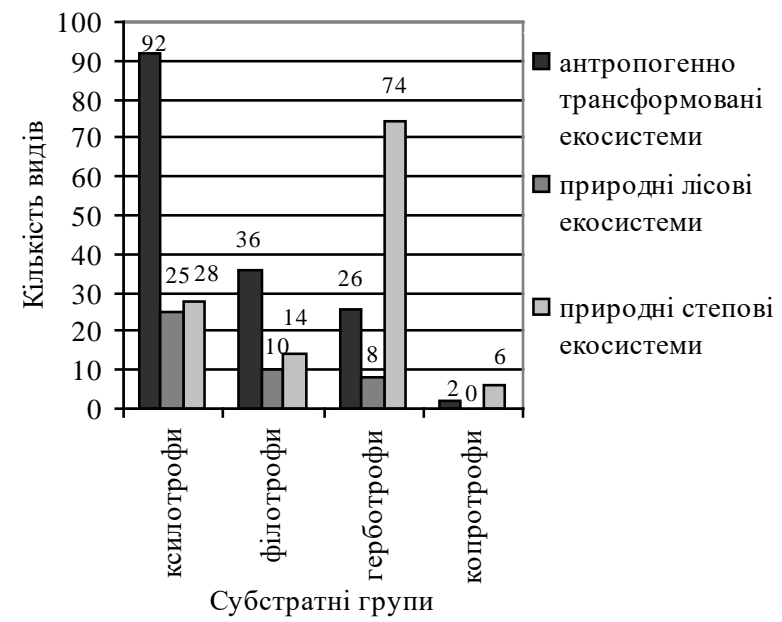

Рис. 4. Співвідношення кількості видів у складі субстратних груп грибів класу Dothideomycetes в антропогенно трансформованих та природних екосистемах степової зони України 
За субстратними групами виявлені види розподіляються таким чином: ксилотрофи - 92 види, філотрофи - 36, герботрофи 26, копротрофи - 2 види. За субстратною приуроченістю в антропогенно трансформованих екосистемах відмічається порівняно більший відсоток ксилотрофних та філотрофних видів (рис. 4). Розповсюдженню ксилотрофів на дослідженій території сприяє поширення штучної лісової рослинності у вигляді лісонасаджень і лісосмуг.

Знайдені види локулоаскоміцетів (за винятком копротрофів) асоційовані зі 178 видами судинних рослин із 112 родів 51 родини (табл. 2). Найбільшу кількість мікроміцетів (65) відмічено на рос- линах родини Rosaceae, по 25 видів - на Fabaceae та Oleaceae, на представниках решти 48 родин - значно меншу кількість видів грибів (табл. 2). Із представниками синантропної флори (22 види) консортивно пов'язаний 31 вид локулоаскоміцетів 316 родів. Серед них найпоширеніші - види роду Cucurbitaria (8), дещо менше видів з родів Mycosphaerella (5), Leptosphaeria та Otthia (по 3 види), 12 родів (Didymosphaeria, Platystomum, Lophiotrema, Phaeosphaeria, Pleospora, Venturia, Didymella, Herpotrichia, Botryosphaeria, Hysterium, Hysterographium, Hysteropatella) представлені одним видом.

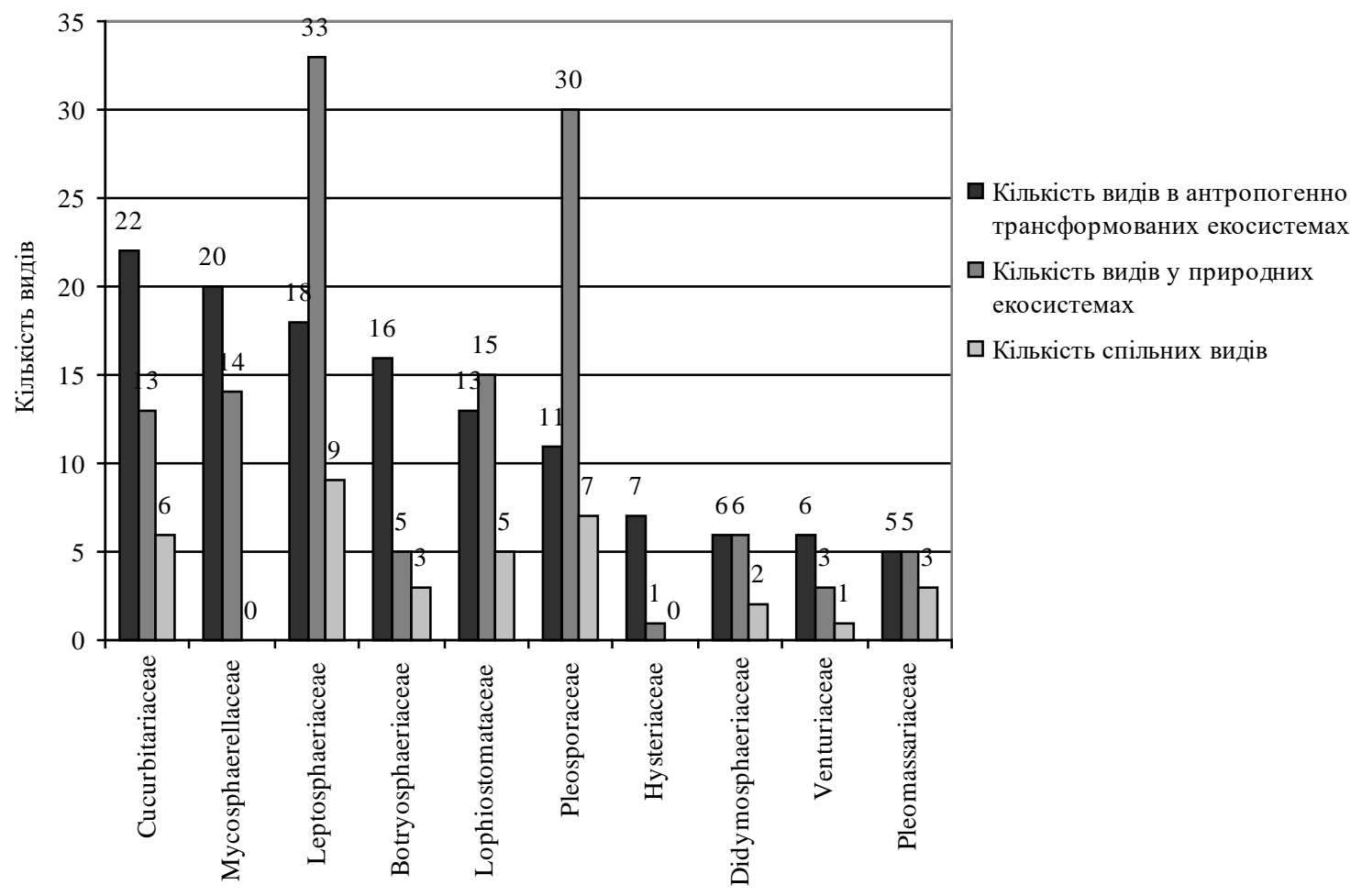

Рис. 2. Співвідношення кількості видів 10 провідних родин класу Dothideomycetes в антропогенно трансформованих та природних екосистемах степової зони України

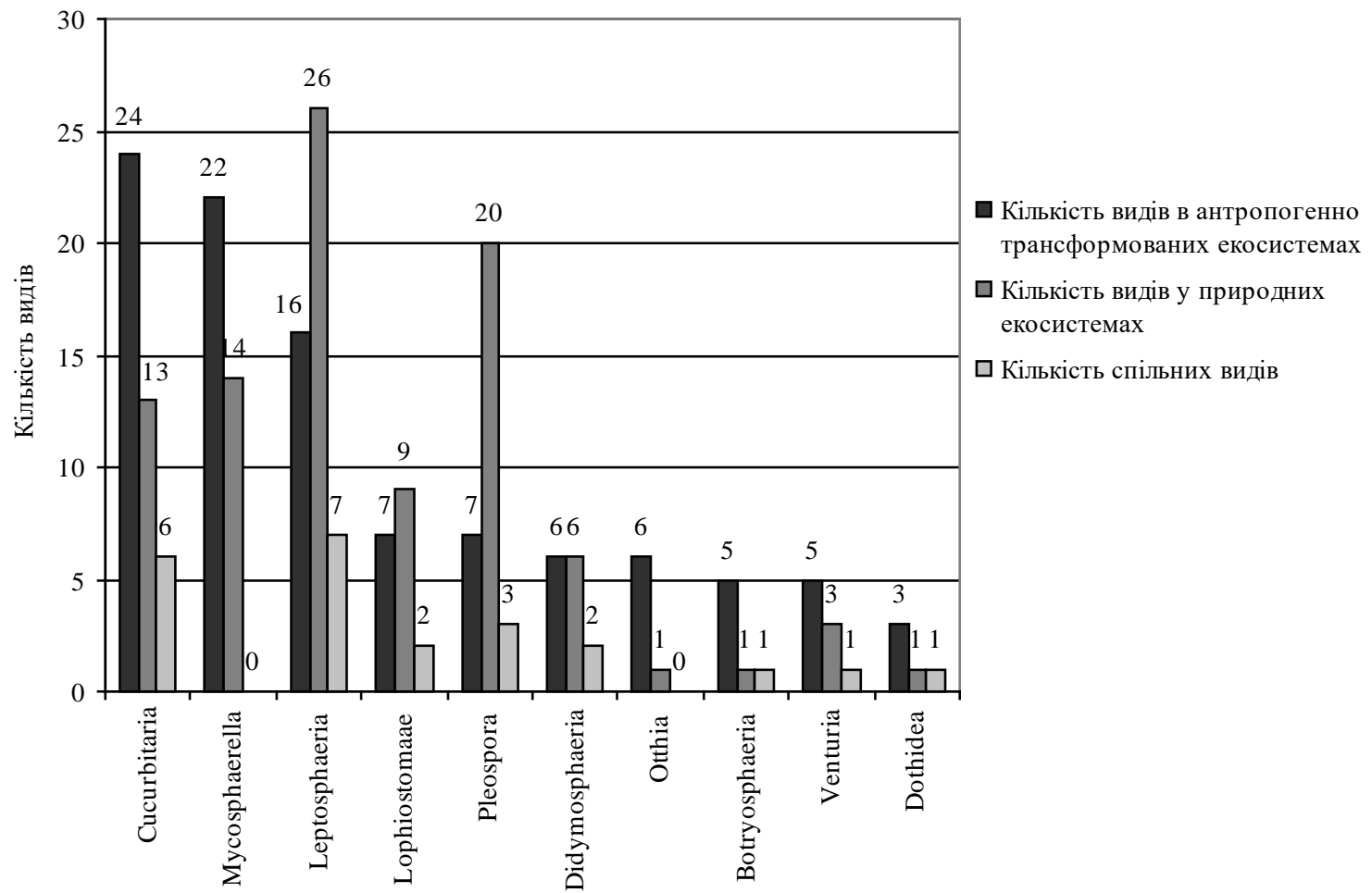

Рис. 3. Співвідношення кількості видів 10 провідних родів класу Dothideomycetes в антропогенно трансформованих та природних екосистемах степової зони України 
Таблиця 2

Розподіл видів грибів класу Dothideomycetes за таксонами живильних рослин антропогенно трансформованих екосистем степової зони України

\begin{tabular}{|c|c|c|}
\hline \multirow{2}{*}{ Родини та роди судинних рослин } & \multicolumn{2}{|c|}{ Кількість видів } \\
\hline & рослин & грибів \\
\hline Aceraceae (Acer) & 6 & 10 \\
\hline Anacardiaceae (Cotinus, Pistacia, Rhus) & 4 & 8 \\
\hline Apiaceae (Eryngium) & 1 & 2 \\
\hline Apocynaceae (Vinca) & 1 & 1 \\
\hline Aquifoliaceae (Ilex) & 1 & 1 \\
\hline Araliaceae (Hedera) & 1 & 1 \\
\hline Asparagaceae (Asparagus) & 1 & 1 \\
\hline $\begin{array}{c}\text { Asteraceae (Achillea, Arctium, Artemisia, Aster, Cichorium, } \\
\text { Helianthus, Ptarmica, Tanacetum, Tragopogon) }\end{array}$ & 10 & 16 \\
\hline Berberidaceae (Berberis, Mahonia) & 4 & 7 \\
\hline Betulaceae (Betula) & 2 & 2 \\
\hline Bignoniaceae (Campsis, Catalpa) & 2 & 3 \\
\hline Brassicaceae (Armoracia, Cardaria, Nasturtium) & 3 & 4 \\
\hline Buddlejaceae (Buddleja) & 1 & 1 \\
\hline Buxaceae (Buxus) & 2 & 3 \\
\hline Caesalpiniaceae (Cercis, Gleditsia) & 3 & 4 \\
\hline Caprifoliaceae (Lonicera, Sambucus, Viburnum) & 6 & 11 \\
\hline Caryophyllaceae (Silene) & 1 & 1 \\
\hline Celastraceae (Euonymus) & 1 & 1 \\
\hline Chenopodiaceae (Chenopodium, Kochia) & 2 & 2 \\
\hline Cucurbitaceae (Lagenaria) & 1 & 1 \\
\hline Elaeagnaceae (Elaeagnus, Hippophaë) & 2 & 4 \\
\hline $\begin{array}{l}\text { Fabaceae (Amorpha, Caragana, Colutea, Cytisus, } \\
\text { Halimodendron, Laburnum, Medicago, Robinia, } \\
\text { Securigera, Sophora, Spartium) }\end{array}$ & 13 & 25 \\
\hline Fagaceae (Quercus) & 3 & 10 \\
\hline Grossulariaceae (Grossularia, Ribes) & 5 & 10 \\
\hline Hippocastanaceae (Aesculus) & 2 & 9 \\
\hline Hydrangeaceae (Philadelphus) & 1 & 3 \\
\hline Iridaceae (Gladiolus) & 5 & 5 \\
\hline Juglandaceae (Juglans) & 1 & 5 \\
\hline Lamiaceae (Hyssopus, Lavandula) & 2 & 2 \\
\hline Lauraceae (Cinnamomum) & 1 & 1 \\
\hline Limoniaceae (Limonium) & 1 & 1 \\
\hline Magnoliaceae (Magnolia) & 1 & 1 \\
\hline Moraceae (Morus) & 2 & 4 \\
\hline $\begin{array}{l}\text { Oleaceae (Forsythia, Fraxinus, Jasminum, Ligustrum, Olea, } \\
\text { Syringa) }\end{array}$ & 11 & 25 \\
\hline Onagraceae (Oenothera) & 1 & 1 \\
\hline Pinaceae (Pinus) & 2 & 3 \\
\hline Plantaginaceae (Plantago) & 1 & 1 \\
\hline Poaceae (Dactylis, Elytrigia, Poa, Triticum) & 6 & 8 \\
\hline Polygonaceae (Rumex) & 1 & 2 \\
\hline Ranunculaceae (Clematis, Delphinium) & 2 & 3 \\
\hline $\begin{array}{l}\text { Rosaceae (Amelanchier, Armeniaca, Cerasus, Crataegus, } \\
\text { Cotoneaster, Fragaria, Kerria, Malus, Mespilus, Padus, } \\
\text { Persica, Prunus, Pyrus, Rhodotypos, Rosa, Rubus, } \\
\text { Sibiraea, Sorbus, Spiraea) }\end{array}$ & 40 & 65 \\
\hline Ruscaceae (Ruscus) & 1 & 1 \\
\hline Salicaceae (Populus, Salix) & 7 & 10 \\
\hline Scrophulariaceae (Verbascum) & 1 & 1 \\
\hline Solanaceae (Hyoscyamus, Lycium) & 2 & 5 \\
\hline Staphyleaceae (Staphylea) & 1 & 1 \\
\hline Tamaricaceae (Tamarix) & 1 & 1 \\
\hline Tiliaceae (Tilia) & 1 & 1 \\
\hline Ulmaceae (Celtis, Ulmus) & 5 & 8 \\
\hline Urticaceae (Urtica) & 2 & 2 \\
\hline Vitaceae (Vitis) & 1 & 1 \\
\hline
\end{tabular}

Найбільшу кількість грибів знайдено на Laburnum anagyroides Medik. i Rubus idaeus L. Найстійкіші консортивні зв'язки із вищими рослинами утворюють Cucurbitaria laburni (Pers.) De Not., C. amorphae (Wallr.) Fuckel, Didymosphaeria rubi Fuckel, Hysterographium fraxini (Pers.) De Not., Leptosphaeria eryngii Fabre, Mycosphaerella cerasella Aderh. Порівняння кількості видів локулоаскоміцетів, відмічених на живильних рослинах 10 провідних родин в антропогенно трансформованих екосистемах із таким у природних виявило певні відмінності (рис. 5). У трансформованних біотопах розповсюдженими рослинами-господарями локулоаскомі- цетів виступають представники родини Rosaceae, у степових - Asteraceae, в лісових - Salicaceae. У цілому, спектр живильних рослин, 3 якими асоційовані локулоаскоміцети, у трансформованих біотопах різноманітніші.

Аналіз поширення видів локулоаскоміцетів за основними типами антропогенно перетворених місцезростань показав такий кількісний розподіл: на територіях ботанічних садів і дендропарків 88 видів, у зелених насадженнях міст - 86, в агрофітоценозах (сади, ягідники, розсадники, городи, поля тощо) - 31, в різних рудеральних місцезростаннях (узбіччя доріг, залізниці, звалища, пустища, занедбані ділянки тощо) - 30, в лісосмугах - 22 види.

Для з'ясування ролі певних видів у формуванні видового спектра локулоаскоміцетів досліджуваної території оцінено їх достаток (стрівальність) за шкалою Стівенсона (рис. 6). За цією шкалою види можна розподілити на рідкісні (відносний достаток менше $0,5 \%)$, випадкові $(0,5-1,5 \%)$, звичайні $(1,5-3,0 \%)$, широко розповсюджені (більше 3,0\%). На території антропогенних біотопів кількість видів локулоаскоміцетів, що трапляються випадково, становить 47\% (73 види), кількість рідкісних - 28\% (44 видів), звичайних - 22\% (34 види). Широко розповсюджені лише 5 видів (3\%): Dothidea sorbi (Wahlenb.) Sacc., Cucurbitaria caraganae P. Karst., C. amorphae, Botryosphaeria dothidea (Moug.) Ces. \& De Not., Otthia spiraeae (Fuckel) Fuckel.

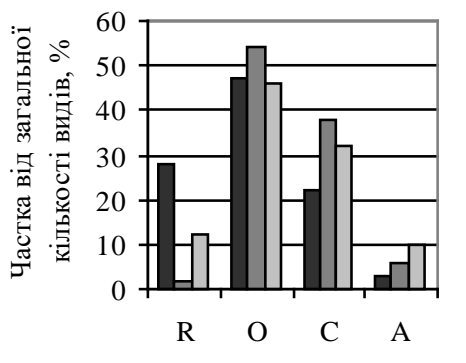

$\square$ антропогенно
трансформовані
екосистеми
$\square$ природні лісові
екосистеми
$\square$ природні степові
екосистеми

Категорії достатку

Рис. 6. Розподіл видів класу Dothideomycetes за категоріями достатку в антропогенно трансформованих та природних екосистемах степової зони України; категорії достатку:

$\mathrm{R}$ (rare) - рідкісно, O (occasional) - випадково,

C (common) - звичайно, A (abundant) - рясно

Порівняння таксономічних спектрів локулоаскоміцетів в антропогенно трансформованих та природних екосистемах за допомогою коефіцієнта дискримінації Стугрена - Радулеску $\left(\mathrm{K}_{\mathrm{sr}}\right)$ підтвердило їх схожість на рівні родин $\left(\mathrm{K}_{\mathrm{sr}}=-0,43\right)$ та родів $\left(\mathrm{K}_{\mathrm{sr}}=\right.$ $-0,12)$, а також високу відмінність на рівні видів $\left(\mathrm{K}_{\mathrm{sr}}=0,64\right)$. Кількість спільних видів, відмічених і в антропогенних, i у природних угрупованнях, незначна (48 видів, $31 \%$ ). У різних типах біотопів формуються специфічні видові комплекси локулоаскоміцетів, причому, як показав усебічний аналіз таксономічної структури, специфічність дослідженої мікобіоти проявляється на видовому рівні, а не на рівні вищих таксонів.

Видовий склад Dothideomycetes в умовах антропогенно трансформованих екосистем певною мірою зумовлений різноманіттям субстратів і рослин-господарів, але чималий вплив на формування дослідженої мікобіоти має фітосанітарний стан угруповань, як це характерно для фітотрофних грибів (Blinkova and Ivanenko, 2014). Як зазначає низка дослідників, значний антропогенний тиск може спричинити істотне зниження видового багатства мікобіоти (Terehova, 2007), підвищення активності фітопатогенного компонента (Stavishenko and Kshnyasev, 2013), зникнення рідкісних і вузькоспеціалізованих видів (Juutilainen et al., 2017).

За результатами наших досліджень, в умовах антропогенно трансформованих екосистем переважають види 3 широкою екологічною амплітудою, серед яких значна кількість - плеоморфні види, частіше гемібіотрофні. Їх поширення можна пояснити наявністю у життєвому циклі стадій із різними трофічними уподобаннями та субстратною приуроченістю, що в цілому сприяє розповсюдженню цих видів. Аналіз достатку видів локулоаскоміцетів 
показав значне зростання частки рідкісних і зменшення частки звичайних видів в антропогенно трансформованих біотопах порівняно $з$ таким у природних біотопах (рис. 6). Така особливість, так само, як і переважання випадкових видів, пов’язана зі строкатістю умов зростання мікроміцетів i значним різноманіттям їх субстратів.

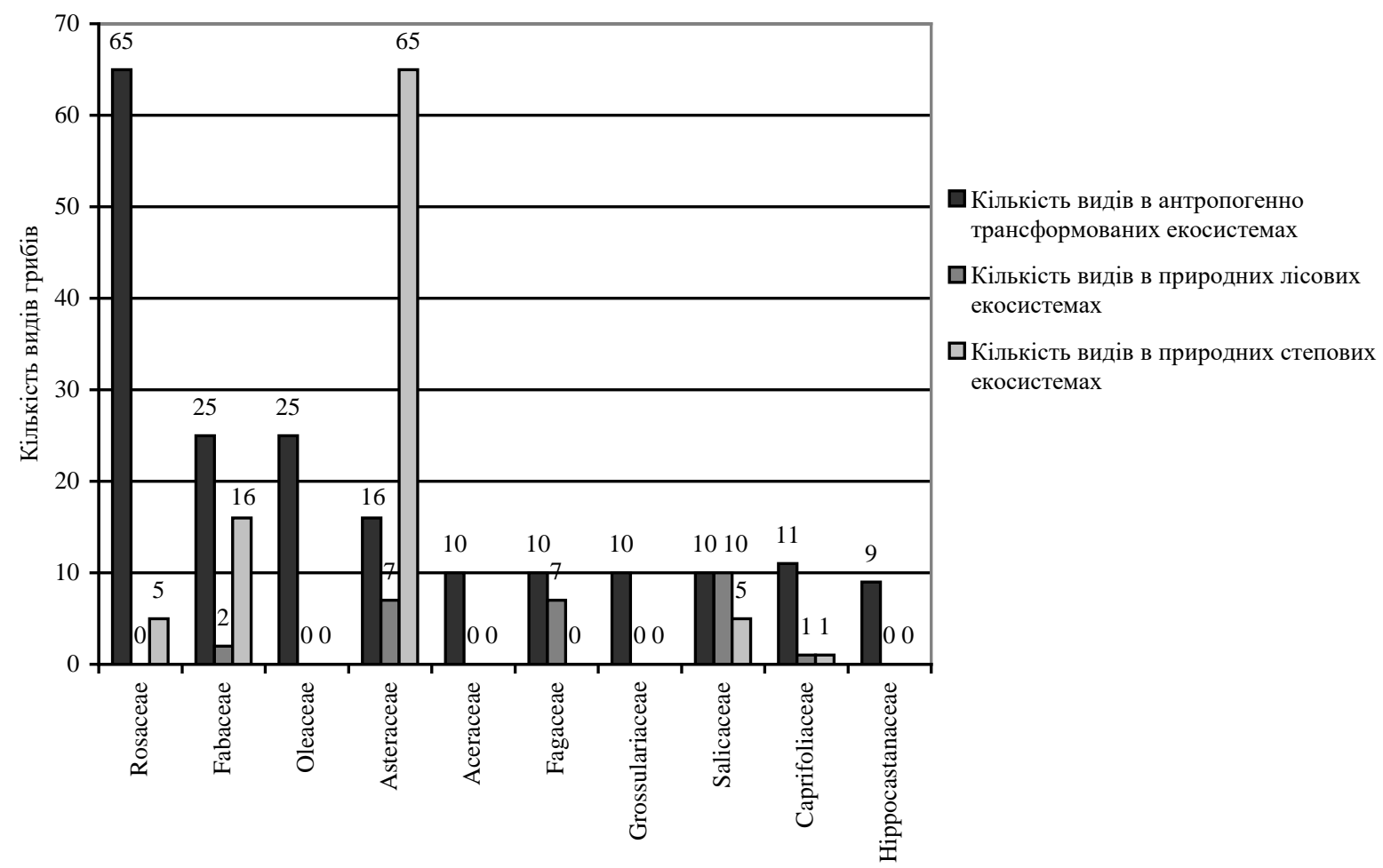

Рис. 5. Співвідношення кількості видів класу Dothideomycetes на живильних рослинах 10 провідних родин в антропогенно трансформованих та природних екосистемах степової зони України

\section{Висновки}

Видове різноманіття грибів класу Dothideomycetes в антропогенно трансформованих екосистемах степової зони України включає 156 видів із 43 родів 19 родин 5 порядків і групи таксонів Incertae sedis підкласів Dothideomycetidae та Pleosporomycetidae. Характерні риси таксономічної структури дослідженої мікобіоти переважання представників порядку Pleosporales, родин Cucurbitariaceae та Mycosphaerellaceae, родів Cucurbitaria та Mycosphaerella.

За трофічними уподобаннями, в антропогенно трансформованих екосистемах відмічено переважання локулоаскоміцетів-сапротрофів, а за субстратною приуроченістю - ксилотрофних та філотрофних видів. Знайдені види грибів утворюють консортивні зв'язки із 178 видами судинних рослин зі 112 родів 51 родини, причому найбільшу кількість мікроміцетів (65 видів) відмічено на рослинах родини Rosaceae. Аналіз достатку видів в антропогенно трансформованих біотопах дослідженої території показав, що 47\% видів трапляються випадково. Широко розповсюджені D. sorbi, C. caraganae, C. amorphae, B. dothidea, O. spiraeae.

В антропогенно трансформованих екосистемах степової зони України, порівняно з природними, кількісно зростає частка видів iз родів Cucurbitaria та Mycosphaerella, а також зменшується частка видів Leptosphaeria та Pleospora. Характерною ознакою антропогенних змін мікобіоти можна вважати збільшення в екологічній структурі частки гемібіотрофних видів. Порівняльний аналіз кількісних і якісних показників структури мікобіоти, просторових і часових змін цих показників може виступати інструментом індикації іiі антропогенної трансформації. Перспективи подальших досліджень - дослідження змін видової структури мікроміцетів за різних типів антропогенного впливу в наземних екосистемах степової зони України.

\section{References}

Bespalova, A. Y., Marfenina, O. E., \& Motuzova, G. V. (2006). Communities of microscopic fungi in contaminated and reference Al-Fe-humus podzols and their influence on copper mobility. Eurasian Soil Science, 39(2), 203-210.

Blinkova, O., \& Ivanenko, O. (2014). Co-adaptive system of tree vegetation and wood-destroying (xylotrophic) fungi in artificial phytocoenoses, Ukraine. Central European Forestry Journal, 60(3), 168-176.

Blinkova, O., \& Ivanenko, O. (2016). Communities of tree vegetation and wooddestroying fungi in parks of the Kyiv city, Ukraine. Central European Forestry Journal, 62(2), 110-122.

Buscardo, E., Rodríguez-Echeverría, S., Freitas, H., De Angelis, P., Pereira, J. S., \& Muller, L. A. H. (2015). Contrasting soil fungal communities in Mediterranean pine forests subjected to different wildfire frequencies. Fungal Diversity, 70(1), 85-99.

Dion, P., \& Nautiyal, C. S. (Eds.). (2008). Microbiology of extreme soils. Springer, Berlin, Heidelberg.

Ellis, M. B., \& Ellis, J. P. (1987). Microfungi on land plants: An identification handbook. Croom Helm, London, Sydney.

Ji, C. Y., Chen, C. J., Wang, X. R., Liu, Y., Liu, J. Y., \& Zeng, B. S. (2017). A report on canker disease of Falcataria moluccana caused by Lasiodiplodia theobromae in China. Crop Protection, 91, 89-92.

Juutilainen, K., Mönkkönen, M., Kotiranta, H., \& Halme, P. (2017). Resource use of wood-inhabiting fungi in different boreal forest types. Fungal Ecology, 27A, 96-106.

Korol'ova, O. V. (2016). Gryby klasu Dothideomycetes lisovyh roslynnyh ugrupovan' stepovoi' zony Ukrai'ny [Dothideomycetes of forest plants communities of the steppe zone of Ukraine]. Bulletin of Taras Shevchenko National University of Kyiv. Biology, 71(1), 61-66 (in Ukrainian).

Lawrence, D. P., Hand, F. P., Gubler, W. D., \& Trouillas, F. P. (2017). Botryosphaeriaceae species associated with dieback and canker disease of bay laurel in northem California with the description of Dothiorella californica sp. nov. Fungal Biology, 121(4), 347-360.

Lee, D.-H., Roux, J., Wingfield, B. D., Barnes, I., Mostert, L., \& Wingfield, M. J. (2016). The genetic landscape of Ceratocystis albifundus populations in South Africa reveals a recent fungal introduction event. Fungal Biology, 120(5), 690-700. 
Leont'ev, D. V. (2008). Floristicheskij analiz v mikologii [Floristic analysis in mycology]. Ranok-NT, Kharkov (in Russian).

Mandić, L., Đukić, D., \& Đorđević, S. (2005). Soil fungi as indicators of pesticide soil pollution. Zbomik Matice Srpske za Prirodne Nauke, 109, 97-102.

Marfenina, O. E. (2005). Antropogennaja ekologija pochvennyh gribov [Anthropogenic ecology of soil fungi]. Medicina Dlja Vseh, Moscow (in Russian).

Matsumura, E., \& Fukuda, K. (2013). A comparison of fungal endophytic community diversity in tree leaves of rural and urban temperate forests of Kanto district, eastern Japan. Fungal Biology, 117(3), 191-201.

Mehl, J. W. M., Slippers, B., Roux, J., \& Wingfield, M. J. (2017). Overlap of latent pathogens in the Botryosphaeriaceae on a native and agricultural host. Fungal Biology, 121(4), 405-419.

Mendes, B., Urbano, P., Alves, C., Morais, J., Lapa, N., \& Oliveira, J. S. (1998). Fungi as environmental microbiological indicators. Water Science et Technology, 38(12), 155-162.

Miller, G. M., Bills, G. F., \& Foster, M. S., (Ed.). (2004). Biodiversity of Fungi: Inventory and monitoring methods. Elsevier Academic Press, Amsterdam.

Newbound, M., Mccarthy, M. A., \& Lebel, T. (2010). Fungi and the urban environment: A review. Landscape and Urban Planning, 96(3), 138-145.

Pavlic-Zupanc, D., Maleme, H. M., Piškur, B., Wingfield, B. D., Wingfield, M. J., \& Slippers, B. (2017). Diversity, phylogeny and pathogenicity of Botryosphaeriaceae on non-native Eucalyptus grown in an urban environment: A case study. Urban Forestry and Urban Greening, 26, 139-148.

Pavlidis, T., Ilieva, M., Bencheva, S., \& Stancheva, J. (2005). Researches on wooddestroying fungi division Ascomycota, classis Ascomycetes. Zbomik Matice Srpske za Prirodne Nauke, 109, 143-148.

Pelleteret, P., Crovadore, J., Cochard, B., Pasche, S., Bovigny, P.-Y., Chablais, R., \& Lefort, F. (2017). Urban London plane tree dieback linked to fungi in the Botryosphaeriaceae. Urban Forestry and Urban Greening, 22, 74-83.

Pereira, A., Geraldes, P., Lima-Fernandes, E., Fernandes, I., Cássio, F., \& Pascoal, C. (2016). Structural and functional measures of leaf-associated invertebrates and fungi as predictors of stream eutrophication. Ecological Indicators, 69, 648-656.

Protopopova, V. V. (1991). Sinantropnaja flora Ukrainy i puti ee razvitija [Synanthropic flora of Ukraine and ways of its development]. Naukova Dumka, Kyiv (in Russian).
Raghavendra, A. K. H., Bissett, A. B., Thrall, P. H., Morin, L., Steinrucken, T. V., Galea, V. J., Goulter, K. C., \& van Klinken, R. D. (2017). Characterisation of above-ground endophytic and soil fungal communities associated with dieback-affected and healthy plants in five exotic invasive species. Fungal Ecology, 26, 114-124.

Rodríguez-Gálvez, E., Guerrero, P., Barradas, C., Crous, P. W., \& Alves, A. (2017). Phylogeny and pathogenicity of Lasiodiplodia species associated with dieback of mango in Peru. Fungal Biology, 121(4), 452-465.

Sakalidis, M. L., Hardy, G. E. S. J., \& Burgess, T. I. (2011). Endophytes as potential pathogens of the baobab species Adansonia gregorii: A focus on the Botryosphaeriaceae. Fungal Ecology, 4(1), 1-14.

Sivanesan, A. (1984). The bitunicate Ascomycetes and their anamorphs. J. Cramer, Hirschberg.

Snieškienè, V., Baležentienè, L., \& Stankevičienè, A. (2016). Urban salt contamination impact on tree health and the prevalence of fungi agent in cities of the central Lithuania. Urban Forestry and Urban Greening, 19(1), 13-19.

Stavishenko, I. V., \& Kshnyasev, I. A. (2013). Response of forest communities of xylotrophic fungi on industrial pollution: Multimodel inference. Biology Bulletin, 40(4), 404-413.

Terehova, V. A. (2007). Mikromicety v ekologicheskoj ocenke vodnyh i nazemnyh ekosistem [Micromycetes in the environmental assessment of aquatic and terrestrial ecosystems]. Nauka, Moscow (in Russian).

Terho, M., Hantula, J. \& Hallaksela, A.-M. (2007). Occurrence and decay patterns of common wood-decay fungi in hazardous trees felled in the Helsinki City. Forest Pathology, 37(6), 420-432.

Tomoshevich, M. A. (2009). Pathogenic mycobiota on trees in Novosibirsk plantations. Contemporary Problems of Ecology, 2(4), 382-387.

Tomoshevich, M. A., \& Banaev, E. V. (2013). Conceming regularities in the structure of pathogenic micromycetes on leaves of woody plants in urban ecosystems of Siberia. Contemporary Problems of Ecology, 6(4), 396-401.

Vivas, M., Kemler, M., Mphahlele, M. M., Wingfield, M. J., \& Slippers, B. (2017). Matemal effects on phenotype, resistance and the structuring of fungal communities in Eucalyptus grandis. Environmental and Experimental Botany, $140,120-127$. 